\title{
A New Check System of Cost Estimation of Project Designs in Japan's Local Governments
}

\author{
Nobuo Nishi (西 喜士) \\ Department of Urban and Civil Engineering, Tokyo City University, \\ 1-28-1 Tamazutsumi, Setagaya-ku, Tokyo 158-8557, Japan \\ Masaru Minagawa (皆川 勝) \\ Department of Urban and Civil Engineering, Tokyo City University, \\ 1-28-1 Tamazutsumi, Setagaya-ku, Tokyo 158-8557, Japan \\ cross $^{r e f}$ http://dx.doi.org/10.5755/j01.ppaa.19.3.26281
}

\begin{abstract}
In Japan, "Pointing and Calling" is a known safety management method that is used to prevent mistakes and ensure safety. This study constructed a new check system, "Verification Meeting/ Simple Verification Meeting", that is based on the Pointing and Calling system and aims to prevent incorrect cost estimations for projects of public works. It also contributes to improved staff morale and professional development. The new check system has five novel items compared with conventional verification methods of cost estimation. The proposed system was put into actual use in Japan, during which time necessary improvements were made. As a result, no mistakes in cost estimation were noted for about three years at the Port and Harbor Bureau of a city in Japan, where the first author of this article worked. The system was further refined and could be adapted for use by all local governments, including those with few staff members.
\end{abstract}

Keywords: incorrect cost estimation; pointing and calling; local governments in Japan; verification method; organization management; human resources development management.

Raktažodžiai: neteisingas išlaidu įvertinimas; delegavimas ir patikra; Japonijos vietos valdžia; patikros metodas; organizacijos valdymas; žmogiškuju ištekliu plètros valdymas.

\section{Introduction}

Local governments in Japan often cancel bids due to incorrect cost estimation of project designs. Most local governments do not officially disclose the information about bid cancellation as it is considered negative information. As a result, planned facilities are not constructed, which greatly impacts public services and decreases staff motivation. Local governments do conduct internal investigations to prevent incorrect cost estimation; however, no local government has yet developed a firm diagnostic model and preventive measures, and there are no academic studies on this issue to the best of our knowledge.

Local governments frequently engage in planning, cost estimation, ceiling price determination, bidding, contracting, construction, supervision, and inspection activities for a variety of building projects. Cost estimation is determining the ceiling price of a project in a bidding procedure through which the contractor is selected. In this project flow, determining the ceiling price is an important part of the bidding process, as the ceiling price limits the maximum bid and is used to determine the minimum bids (Ohashi, 2014; Kinoshita, 2017). In other countries such as the United States and France, there is no ceiling price system with an upper limit for bids, as there is in Japan. Other countries have set ceiling prices as a guide for budget control (Ding, 2016; Netscher, 2017). 
Thus, in other countries, unlike in Japan, it is difficult to find records on incorrect cost estimations. If the ceiling price is determined incorrectly and the above sequence of actions is undertaken, construction will be carried out under an incorrect contract. This problem can be resolved by either reviewing the ceiling price system or preventing mistakes in estimations. Regarding the former, previous research has discussed the current bidding contract system in Japan, including the ceiling price scheme (Ohashi, 2014; Kinoshita, 2017). In this paper, the discussion regarding the bid contract system is excluded. Instead, the present article focusses on the second method, specifically, the prevention of incorrect cost estimations.

Human error is a known issue, and local governments often halt bidding in the face of incorrect cost estimations, which greatly affects the services provided to residents. This problem has been discussed at great length in the literature (Nikkei Construction, 2010; 2013a; 2013b). Moreover, studies (Max Produce, 2016; Mynavi Corporation, 2017; Tokyo Future University, 2018) indicate that the item "work mistakes" ranks high among the factors that reduce staff motivation. Therefore, incorrect cost estimation is also an important social problem that must be studied and resolved academically.

For example, in a certain city in Japan, incorrect cost estimations occurred four times a month in a row, and the bidding procedures were cancelled, which became a major social problem. In response, the local government has built a practical system to prevent incorrect cost estimation through improved human resource development management and organizational management. In this paper, we theoretically and academically study this successful case and prove that the management method used here can be universally applied to many organizations.

In this study, a new check system aimed at preventing incorrect cost estimation of the project design was constructed and put to actual use for about three years. During this period of time, necessary adjustments were made to improve the comprehensiveness of the system. This enabled the horizontal deployment of the system in small- and medium-sized local governments that find it difficult to hire many staff in the cost estimation department. To the best of our knowledge, there have been no studies related to incorrect cost estimation in Japan. Therefore, this paper can contribute towards developing this field. For the purposes of this paper, we define the Verification Meeting, which is the keystone of the new check system, as a new method. To the best of our knowledge, prior to it, there existed no verification method of cost estimation that involved multiple staff members in the discussion.

The structure of the paper is as follows. First, a successful case of the application of this method in a certain city is introduced. Important elements of the human resources development of young staff are also analyzed from the case results. Next, we analyze why the method described was successful by comparing it with the structure of "Pointing and Calling." Afterwards, we describe a new check system aimed at preventing incorrect cost estimation corresponding to design and the novel items of this system are highlighted. Finally, the conclusions are presented.

\section{New Cost Estimation Check System: "Verification Meeting"}

This section refers to reports (Kawasaki City, 2016a; 2018) compiled by specific cities. Specifically, the authors organized a report about incorrect cost estimation, which was compiled by a certain city. The first author of this study is a key member of the report coordinating committee. Furthermore, the first author ran a Verification Meeting by trial and error. A Verification Meeting is a verification method based on new ideas that can perform verification work and management of human resource development at the same time. The content regarding the operation of the Verification Meeting introduced in this paper was mainly devised by the first author for the Secretariat department of the government. The Verification Meeting concept was introduced more widely in the world's largest newspaper, Yomiuri Shimbun, on July 4, 2018. As was mentioned before, the literature does not refer to any previous methods of cost estimation verification that involve multiple staff members in the discussion, as was done in the Verification Meeting discussed in the present paper. 


\section{Overview of the Verification Meeting}

The Verification Meeting is a verification method proposed by the first author of this study, who hypothesized that gathering a large number of staff and verifying the document from many perspectives could prevent incorrect cost estimation. Figure 1 shows the history of the Verification Meeting.

\begin{tabular}{|c|c|c|c|}
\hline Conventional & $\begin{array}{c}\text { First period } \\
\text { (November 2015 } \\
\text {-October 2016) }\end{array}$ & $\begin{array}{c}\text { Second period } \\
\text { (November } 2016 \\
\text {-March 2017) }\end{array}$ & $\begin{array}{c}\text { Third period } \\
\text { (April 2017 } \\
\text {-March 2018) } \\
\end{array}$ \\
\hline Cost estimation staff & $\begin{array}{c}\text { Cost estimation } \\
\text { staff }\end{array}$ & Cost estimation staff & Cost estimation staff \\
\hline$\downarrow$ & $\downarrow$ & $\downarrow$ & $\downarrow$ \\
\hline Pre-verification staff & $\begin{array}{c}\text { Pre-verification } \\
\text { staff }\end{array}$ & Pre-verification staff & Pre-verification staff \\
\hline$\downarrow$ & $\downarrow$ & $\downarrow$ & $\downarrow$ \\
\hline $\begin{array}{cc}\text { OK } & \text { NG } \\
& \text { (Return) } \\
\downarrow & \end{array}$ & $\begin{array}{l}\text { Cost estimation } \\
\text { staff } \\
\text { Pre-verification } \\
\text { staff }\end{array}$ & $\begin{array}{l}\text { Cost estimation staff } \\
\text { Pre-verification staff }\end{array}$ & $\begin{array}{l}\text { Cost estimation staff } \\
\text { Pre-verification staff }\end{array}$ \\
\hline Deputy Manager & Verification Leader & & \\
\hline$\downarrow$ & Verification staff & & \\
\hline Manager & $\begin{array}{c}\text { Verification } \\
\text { assistant }\end{array}$ & Verification assistant & Verification assistant \\
\hline$\downarrow$ & Secretariat & Secretariat & Secretariat \\
\hline \multirow[t]{10}{*}{ General Manager } & $\downarrow$ & $\downarrow$ & Secretariat assistant \\
\hline & $\begin{array}{cc}\text { OK } & \text { NG } \\
& \text { (Return) } \\
\downarrow & \end{array}$ & $\begin{array}{cc}\text { OK } & \text { NG } \\
& \text { (Return) } \\
\downarrow & \end{array}$ & 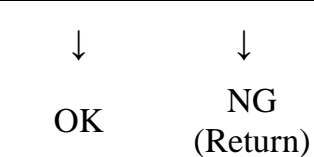 \\
\hline & Deputy Manager & 【Check Meeting】 & $\downarrow$ \\
\hline & $\downarrow$ & Deputy Manager & 【Check Meeting】 \\
\hline & Manager & Cost estimation staff & Deputy Manager \\
\hline & $\downarrow$ & $\downarrow$ & Cost estimation staff \\
\hline & General Manager & Manager & $\downarrow$ \\
\hline & & $\downarrow$ & Manager \\
\hline & & General Manager & $\downarrow$ \\
\hline & & & General Manager \\
\hline
\end{tabular}

Fig.1. History of Verification Meetings 
Table 1 shows the names, main roles and involvement of each staff member for each period. Figure 2 shows the model diagram of the Verification Meeting.

Table 1. Name, main role and installation period of each staff member

\begin{tabular}{|c|c|c|}
\hline NAME & MAIN ROLE & PERIOD \\
\hline $\begin{array}{l}\text { Cost estimation } \\
\text { staff }\end{array}$ & Perform cost estimation & \multirow{2}{*}{$\begin{array}{l}1 \\
2 \\
3\end{array}$} \\
\hline $\begin{array}{l}\text { Pre-verification } \\
\text { staff }\end{array}$ & $\begin{array}{l}\text { Conduct verification at the preliminary submission } \\
\text { Verify Meeting stage together } \\
\text { with Cost estimation staff }\end{array}$ & \\
\hline $\begin{array}{l}\text { Verification } \\
\text { Leader }\end{array}$ & Participate in Verification Meeting and run individual Verification Meetings & 1 \\
\hline Verification staff & $\begin{array}{l}\text { Senior staff who participate in Verification Meeting and assist the Verification } \\
\text { Leader }\end{array}$ & 1 \\
\hline Verification staff & $\begin{array}{l}\text { Participate in Verification Meeting and run individual Verification Meetings } \\
\text { Senior staff who play the role of Verification leader }\end{array}$ & $\begin{array}{l}2 \\
3\end{array}$ \\
\hline Verification staff & $\begin{array}{l}\text { Participate in Verification Meeting and assist Verification Leader } \\
\text { Senior staff who play the role of Verification leader } \\
\text { Senior staff who partially play the role of Secretariat } \\
\text { (Secretariat assistant) }\end{array}$ & 3 \\
\hline $\begin{array}{l}\text { Verification } \\
\text { assistant }\end{array}$ & $\begin{array}{l}\text { Junior staff who participate in } \\
\text { Verification Meeting } \\
\text { and assist Verification staff }\end{array}$ & \multirow{5}{*}{$\begin{array}{l}1 \\
2 \\
3\end{array}$} \\
\hline Deputy Manager & Decision-maker & \\
\hline Manager & Decision-maker & \\
\hline General Manager & Decision-maker & \\
\hline Secretariat & $\begin{array}{l}\text { The Deputy Manager who formulates management policies for all Verification } \\
\text { Meetings } \\
\text { (The first author) }\end{array}$ & \\
\hline
\end{tabular}

Source: Authors.

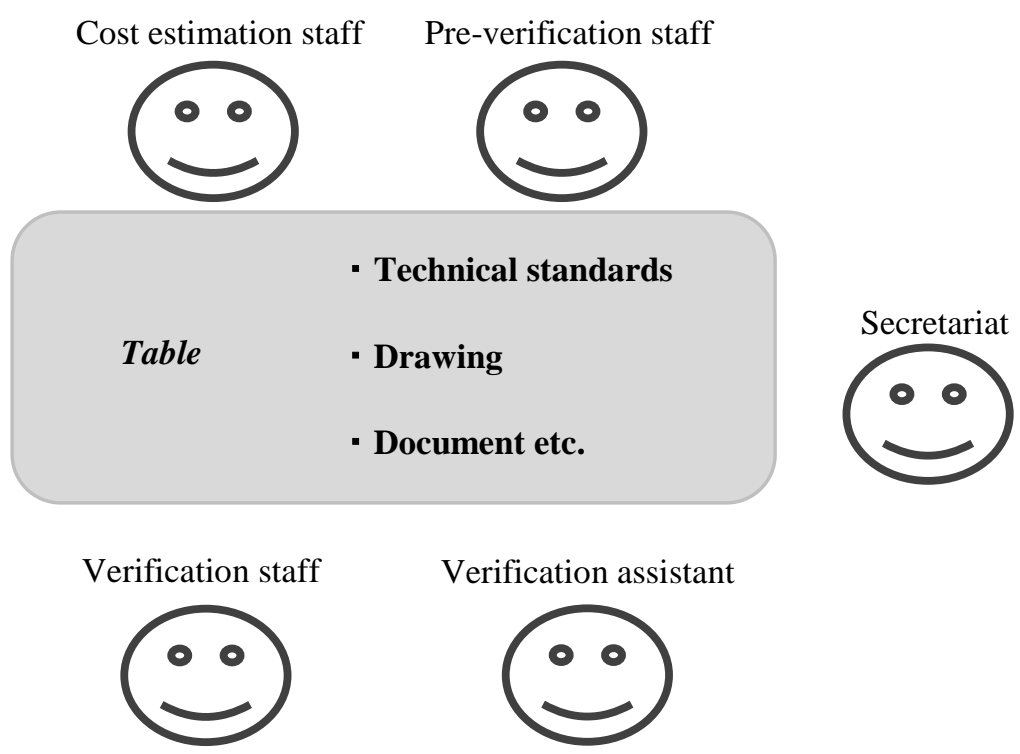

Fig.2. Model diagram of a Verification Meeting

Source: Authors. 
The Verification Meeting comprised Cost estimation staff, Pre-verification staff, the Verification Leader (only first period), Verification staff and the Verification assistant. Each Verification Meeting is operated by the Verification Leader (first period) or Verification staff (second and third periods). The Deputy Manager oversees the work of the Verification Leader and the Senior staff are in charge of the Verification staff.

Cost estimation staff verbally explain the details of the cost estimation. The Verification Leader (only first period), the Verification staff, and Verification assistant ask questions and the Cost estimation staff can respond immediately. If the Verification Leader, Verification staff and Verification assistant are not satisfied with the opinion of the Cost estimation staff, they will repeat the question or ask other questions. This will create a lively discussion. During this process, Cost estimation staff, Pre-verification staff, Verification staff and the Verification assistant can look at and listen to each other, point with their fingers, use visual interaction and oral communication.

Conventionally, after completion of the work by the Cost estimation staff, verification is performed by the Pre-verification staff, and if it is passed by them, it reaches the Deputy Manager, Manager and General Manager for approval. When a Verification Meeting is introduced, verification is performed by Pre-verification staff after verification by Cost estimation staff is completed. Even if it passes through all the other stages, if it does not pass at the Verification Meeting, it will not proceed to the decision-making stage of the Deputy Manager, Manager and General Manager.

\section{First period (November 2015 to October 2016)}

During this period, every effort was made to eliminate incorrect cost estimations. The Verification Meeting involved numerous staff members, and it was chaired by the Deputy Manager, who had attended organization management training. Due to the initial unfamiliarity with the process, verification took about two to three days per estimation. During this period, human resources development management for the Junior staff was conducted on a trial basis. The Senior staff had to explain the technology to the Junior staff and the Verification Meeting proved to be a mechanism that enables the effective management of human resources development. This judgment is based on the opinions and impressions of the Senior staff who participated in the Verification Meeting. Specifically, the Senior staff mentioned that they were actively asked various questions by the Junior staff belonging to another organization. We think that, unlike an abstract opinion, an opinion that shows a concrete attitude is credible.

Table 2. Problems in the first period and items addressed in the second period

\begin{tabular}{|c|l|c|}
\hline \multicolumn{2}{|c|}{ PROBLEMS IN THE FIRST PERIOD } & $\begin{array}{l}\text { ITEMS ADDRESSED IN THE SECOND } \\
\text { PERIOD }\end{array}$ \\
\hline (1) & $\begin{array}{l}\text { For Verification staff and Verification assistant, it is } \\
\text { burdensome to participate for 2-3 days per cost estimation. }\end{array}$ & $\begin{array}{l}\text { The weight of the incorrect cost } \\
\text { estimation prevention is most } \\
\text { important. }\end{array}$ \\
\hline (2) & $\begin{array}{l}\text { It could be assumed that each Verification Meeting could be } \\
\text { managed by Verification staff alone. }\end{array}$ & $\begin{array}{l}\text { The Deputy Manager does not } \\
\text { participate in the Verification } \\
\text { Meeting. }\end{array}$ \\
\hline (3) & $\begin{array}{l}\text { Verification Meeting from time to time because of his } \\
\text { duties. }\end{array}$ & $\begin{array}{l}\text { A check Meeting" is newly introduced as a } \\
\text { supplement to the Verification Meeting. }\end{array}$ \\
\hline
\end{tabular}

Source: Authors.

Table 2 shows the problems in the first period and the items reflected in the second period. As shown in Table 2, the opinion that the Verification Meeting was too much of a burden in addition to the regular work of the staff was extracted as a problem and addressed in the second period. Another problem noted by staff was that it was not desirable for the Deputy Manager, who had to leave from 
time to time because of his duties, to miss parts of the Verification Meeting. This was also addressed in the second period.

\section{Second period (November 2016 to March 2017)}

In this period, operations continued, with the problems from the first period taken into consideration. In the second period, we focused on preventing miscalculations through the Verification Meeting and aimed to complete verification in about a day. The position of Verification Leader, which was established to run individual Verification Meetings during the first period, was abolished, and Verification staff were entrusted with this role. Furthermore, a "Check Meeting" was set up as a new mechanism to complement it. Table 3 shows the role of the Check Meeting.

\section{Table 3. The role of the Check Meeting}

\begin{tabular}{|c|l|}
\hline ROLE & $\begin{array}{l}\text { The Deputy Manager checks the content of the discussions at the Verification } \\
\text { Meeting face-to-face with the Cost estimation staff. }\end{array}$ \\
\hline $\begin{array}{c}\text { STAFF } \\
\text { COMPOSITION }\end{array}$ & $\begin{array}{l}\text { - Deputy Manager } \\
\text { Cost estimation staff }\end{array}$ \\
\hline
\end{tabular}

Source: Authors.

As in the first period, the Verification Meeting was confirmed to be an achievement of the "effective management of human resources development". As mentioned in the section regarding the first period, this judgment is also based on the opinions and impressions of the Senior staff who participated in the Verification Meeting. Table 4 shows the problems in the second period and the items addressed in the third period. As shown in Table 4, during the third period, the effect of the organization management training was confirmed on a trial basis.

Table 4. Problems in the second period and the items addressed in the third period

\begin{tabular}{|c|c|}
\hline $\begin{array}{c}\text { PROBLEMS IN THE } \\
\text { SECOND PERIOD }\end{array}$ & ITEMS ADDRESSED IN THE THIRD PERIOD \\
\hline \multirow{2}{*}{ None } & $\begin{array}{l}\text { Among the Secretariat's roles, which include drafting the } \\
\text { overall management and operation policy for Verification } \\
\text { Meetings, only one Verification staff member is responsible } \\
\text { for selecting and adjusting all Verification Meetings for the } \\
\text { fiscal year. }\end{array}$ \\
$\begin{array}{l}\text { Confirm the effectiveness of organization management } \\
\text { training on a trial basis. }\end{array}$ \\
\hline
\end{tabular}

Source: Authors.

\section{Third period (April 2017 to March 2018)}

As in the second period, the Verification Meeting was confirmed to be an achievement of the effective management of human resources development that can be used beyond the organization frame. During the first, second and third periods, it was confirmed that the management of human resources development of the Junior staff was possible at the Verification Meeting. As mentioned in the sections on the first and second periods, this judgment is also based on the opinions and impressions of the Senior staff who participated. 
During the first and second periods, the Secretariat selected and coordinated all Verification Meetings during the year so that an equal number of Verification Meetings was held for all four Verification staff. In contrast, among the roles of the Secretariat in charge of drafting the overall management and operation policy for the Verification Meeting, only one Verification staff member was responsible for selecting and adjusting all Verification Meetings for the fiscal year. Table 5 shows the ratio of the number of Verification Meetings held by each Verification staff member in the fiscal year. As seen in Table 5, one Verification staff member could not evenly distribute the number of Verification Meetings held by each member among all the Verification Meetings in the fiscal year. In other words, because of poor organizational management, the number of Verification Meetings held by each Verification staff member was different. We analyze this from the viewpoint of human resources management training.

Table 5. Percentage of Verification Meetings held by each Verification staff

\begin{tabular}{|c|c|c|c|c|}
\hline $\begin{array}{c}\text { VERIFICATION } \\
\text { STAFF }\end{array}$ & $\begin{array}{c}\text { Verification staff } \\
\text { A }\end{array}$ & Verification staff & Verification staff & Verification staff \\
\hline $\begin{array}{c}\text { PERCENTAGE } \\
\text { OF EVENTS } \\
\text { HELD }\end{array}$ & About $31 \%$ & About $35 \%$ & About $17 \%$ & About $17 \%$ \\
\hline \multicolumn{4}{|c}{ Source: Authors. }
\end{tabular}

The "judgment" and "organizational management" skills required in the role of Deputy Manager as shown in Table 6 are not required in the role of the Senior staff as shown in Table 7. The training of Deputy Manager involves training in "organizational management," whereas Senior staff are not responsible for the roles of "judgment" and "organizational management" in normal operations. This accounts for the results shown in Table 4. In other words, in the first and second periods, when the Secretariat who is the Deputy Manager conducts the selection and adjustment of all the Verification Meetings in the fiscal year, the number of Verification Meetings held by each Verification staff member was such that it did not make a difference. Therefore, the effectiveness of organizational management training was confirmed.

\section{Table 6. Role of the Deputy Manager}

\begin{tabular}{|l|l|}
\hline & Planning \\
ROLES OF THE & Office work business implementation \\
DEPUTY MANAGER & $\begin{array}{l}\text { Eudganation and adjustment } \\
\text { Oudganization management }\end{array}$ \\
\hline
\end{tabular}

Source: Kawasaki City (2016b)

Table 7. Role of the Senior staff

\begin{tabular}{|l|l|}
\hline ROLES OF THE & Knowledge and technology \\
SENIOR STAFF & Teamwork \\
& Explanation and reception \\
& Business execution \\
\hline
\end{tabular}




\section{Management of human resources development for Junior staff}

This section refers to reports (Kawasaki City, 2016a; 2018) compiled by specific cities. To make the Verification Meetings successful, we must ensure the success of the management of human resources development for the Junior staff. To that end, a special system called "Junior Meeting" was created because it was necessary to properly understand the characteristics of the Junior staff. The Junior Meeting is set up so that Junior staff members can share their daily questions with others in the same age group to improve their civil engineering knowledge. The Junior Meeting implemented the management of human resources development by changing the management method in each fiscal year for 2016 and 2017.

\section{Transformation}

Table 8 shows the transformation of the Junior Meeting by comparing the periods and making the differences easy to understand. Based on these results, it was decided that the content of the program in 2016 (first period and second period) be reversed for 2017 (third period).

Table 8. The transition of the Junior Meeting

\begin{tabular}{|c|c|c|c|}
\hline \multicolumn{2}{|r|}{ ITEM } & \multirow{2}{*}{\begin{tabular}{l}
\multicolumn{1}{c}{2016} \\
$\begin{array}{l}\text { (FIRST PERIOD) } \\
\text { (SECOND PERIOD) }\end{array}$ \\
- Junior staff are not asked \\
about their willingness to \\
participate
\end{tabular}} & \multirow{2}{*}{$\begin{array}{l}\begin{array}{l}2017 \\
\text { (THIRD PERIOD) }\end{array} \\
\text { - The decision on participation } \\
\text { is heard }\end{array}$} \\
\hline (1) & Staff selection & & \\
\hline (2) & $\begin{array}{c}\text { Content of } \\
\text { implementation }\end{array}$ & - Leave it to Junior staff freely & $\begin{array}{l}\text { - Clarified the content of } \\
\text { implementation in four } \\
\text { departments }\end{array}$ \\
\hline (3) & Secretariat & $\begin{array}{l}\text { - Without setting the } \\
\text { Secretariat }\end{array}$ & - Setting the Secretariat \\
\hline & Keywords & $\begin{array}{l}\text { Ignoring intentions } \\
\text { Self-management }\end{array}$ & $\begin{array}{l}\text { Respect for will } \\
\text { Management and operation }\end{array}$ \\
\hline & Result & Failure & Success \\
\hline
\end{tabular}

Source: Authors.

In 2016, the participants were allowed to participate and operate independently, ignoring the will of the individual, whereas in 2017, the intention of the individual was respected and the administration of the association was managed by the Secretariat. While the 2016 attempt failed, 2017 was successful. In addition, this success/ failure judgment was based on the opinions of the Junior staff who were interviewed. Specifically, the Junior staff members said that it was meaningful to hear the worries and attitudes of other Junior staff members toward work. We think that, unlike an abstract opinion, an opinion that shows a concrete attitude is credible. Since 2018 we have decided to adopt the successful method and we continue to operate in this manner.

\section{Analysis and discussion}

In 2016, the management of the Junior Meeting based on "Ignoring intentions" and "Selfmanagement" failed, while in 2017, the management of the Junior Meeting based on "Respect for will" and "Management and operation" succeeded. As a method of communicating with young people 
in recent years, the importance of "Respect for will" and "Management and operation" is described in the literature (Nambo, 2016; Adachi, 2004, respectively). These tend to be similar to the results shown in Table 8, because, as shown in Table 8, the keywords for success are "Respect for will" and "Management and operation."

In Verification and Junior Meetings, Senior staff create a well-managed and friendly atmosphere with "respect for will" of the Junior staff. Thus, it was confirmed that creating many opportunities for the management of human resources development in daily work would be the key to successful management of the Junior staff.

The importance of creating opportunities in daily work can be explained on the basis of objective data (Figure 6) from the literature (Global Consulting Team, 2018). Figure 3 shows that the number of new employees who desire a workplace with less overtime has been increasing yearly, indicating the need for the management of human resources development during regular work hours rather than overtime.

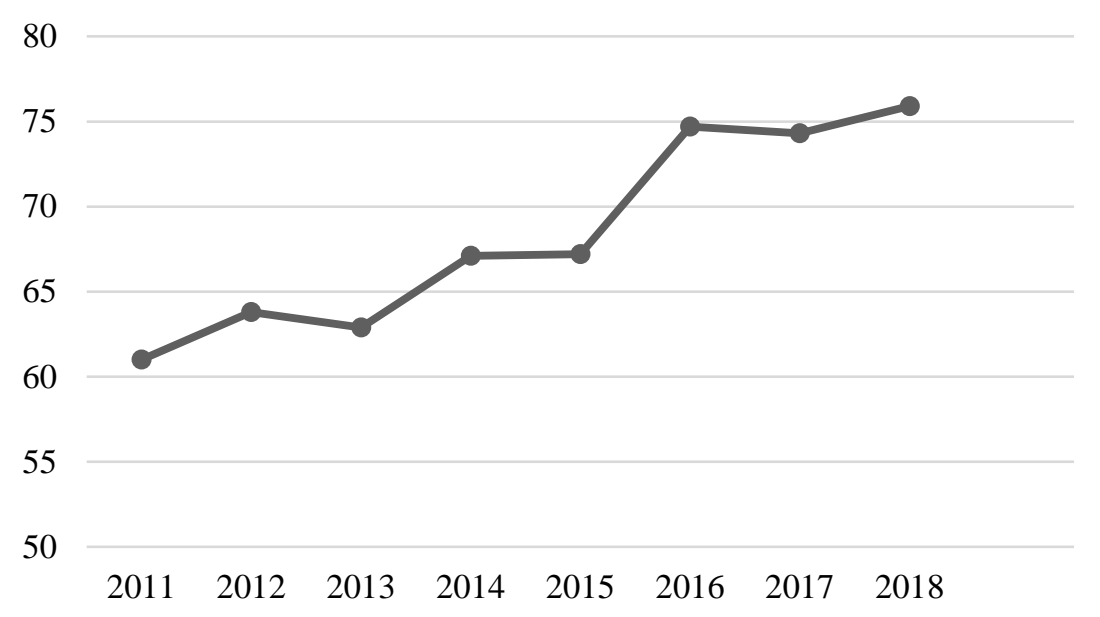

Fig. 3. Desired percentage of workplaces that have less overtime and where employees can have more free time.

Source: Authors.

\section{Analysis of the success factors of the Verification Meeting}

We analyzed the success of the Verification Meeting and for the three-year time period in which it was initially used, no errors in cost estimations were found. We compared the structure of "Pointing and Calling" (Kiyomiya, Ikeda, Tomita, 1965; Japan International Center for Occupational Safety and Health, 1999; Kasahara, Shimazaki, Ishida, et al., 2013), a well-known method of safety management, with the structure of the Verification Meeting. In addition, we analyzed the "phase theory," which is the structural theory of "Pointing and Calling."

\section{Human error prevention by "Pointing and Calling"}

"Pointing and Calling" is a typical example of a human error countermeasure, performed by workers at a construction site. The effects of Pointing and Calling outside of the construction industry have been confirmed in the literature (Kiyomiya, Ikeda, Tomita, 1965; Japan International Center for Occupational Safety and Health, 1999; Kasahara, Shimazaki, Ishida, et al., 2013). Figure 4 shows the general flow of Pointing and Calling. In dangerous workplaces, Pointing and Calling is conducted as a risk prediction activity (Kiyomiya, Ikeda, Tomita, 1965; Japan International Center for Occupational Safety and Health, 1999; Kasahara, Shimazaki, Ishida, et al., 2013). This is an act of calling out while pointing and checking for safety and may be performed alone or as a group. Humans tend to make errors depending on their mood. One way to prevent this is through using both Pointing and Calling. "Pointing and Calling" is a combination of "Pointing" and "Calling," and it is much 
more effective to combine them together than perform only one of them (Ministry of Health, Labor, and Welfare, 2019).

\begin{tabular}{|c|}
\hline Look closely at the target \\
\hline$\downarrow$ \\
\hline Point to the target with your finger \\
\hline$\downarrow$ \\
\hline Put your finger to your ear \\
\hline Wave your right hand \\
\hline
\end{tabular}

Fig. 4. Desired percentage of workplaces that have less overtime and where employees can have more free time Source: Ministry of Health, Labor, and Welfare.

\section{"Phase Theory"}

The mechanism by which Pointing and Calling is effective for security measures is explained by the "Phase Theory" (Hashimoto, 1994; Nagamachi, 1995). Table 9 shows a comparison of the phase stages, consciousness modes, physiological states and error rates. Phase 0 is a time when one is unconscious or has lost consciousness. In Phase I, consciousness is more blurred than usual, strong inattentiveness continues, and many errors occur. The neutral state of consciousness is Phase II, and two-thirds to three-quarters of work occurs during Phase II. In Phase III, there are almost no inadvertent errors, while the brain can maintain the highest level of safety awareness. In Phase IV, the cerebral energy level is very high due to excessive tension and emotional excitement (Hashimoto, 1994; Nagamachi, 1995).

Considering the levels of consciousness in this way, the ideal is Phase III, but it is not easy to maintain this phase because of human frailties. Therefore, it is usually effective to take Phase II and intentionally change the consciousness from Phase II to Phase III as a safety and health measure in situations where accidents are likely to occur. Pointing and Calling plays the role of a switch that prompts a "gear change" from Phase II to Phase III. The ability of Pointing and Calling to prevent human errors has been studied and proven in medical practice (Kawada, Miyakoshi, Fujii, et al., 2011).

Table 9. Awareness phase and human error incidence

\begin{tabular}{|c|c|c|c|}
\hline PHASE & $\begin{array}{c}\text { AWARENESS } \\
\text { MODE }\end{array}$ & $\begin{array}{c}\text { PHYSIOLOGICAL } \\
\text { CONDITION }\end{array}$ & ERROR RATE \\
\hline 0 & $\begin{array}{c}\text { Unconscious } \\
\text { Syncope }\end{array}$ & Sleep & 1.0 \\
\hline I & $\begin{array}{c}\text { Blurred } \\
\text { consciousness }\end{array}$ & $\begin{array}{c}\text { Fatigue } \\
\text { Dozing }\end{array}$ & 0.1 or more \\
\hline II & $\begin{array}{c}\text { Normal } \\
\text { Relaxed }\end{array}$ & $\begin{array}{c}\text { At rest } \\
\text { During regular work }\end{array}$ & $0.01 \sim 0.00001$ \\
\hline III & $\begin{array}{c}\text { Normal } \\
\text { Clear state }\end{array}$ & During activities & 0.000001 or less \\
\hline IV & Excitement & Panic & 0.1 or more \\
\hline
\end{tabular}

Source: Authors. 


\section{Verification Meeting and Pointing and Calling}

Table 10 shows the features and advantages of the Verification Meeting compared with Pointing and Calling. As mentioned in detail in the section "Overview of the Meeting," the Verification Meeting includes four actions: everyone is given opportunities to point with fingers, to use visual interaction and oral communication, and to listen. These four actions are exactly the basic actions of Pointing and Calling (Hashimoto, 1994; Nagamachi, 1995). During these four actions, the brain moves actively, thinking becomes positive, and verification accuracy improves. Therefore, it was not accidental that the Verification Meeting was successful; rather, it could be concluded that it was an effective cost estimation check system as an application of Pointing and Calling. In addition, as shown in Table 10, the Verification Meeting provides a forum for the effective management of human resources development that goes beyond the usual organizational boundaries.

Table 10. Verification Meeting features and benefits

\begin{tabular}{|c|c|}
\hline FEATURES & BENEFITS \\
\hline $\begin{array}{l}\text { 【 Feature (1) 】 } \\
\text { Cost estimation staff } \\
\text { Pre-verification staff } \\
\text { Verification staff } \\
\text { Verification assistant } \\
\text { Gathered together } \\
\text { Everyone verifies by pointing with their } \\
\text { fingers, using visual interaction, } \\
\text { communicating orally, and listening and } \\
\text { confirming. }\end{array}$ & $\begin{array}{l}\text { - Checking from many viewpoints will lead to the } \\
\text { prevention of incorrect cost estimations due to } \\
\text { lack of knowledge. } \\
\text { - With the participation of many staff members, it } \\
\text { is possible to collect considerable information, } \\
\text { which leads to the prevention of incorrect cost } \\
\text { estimations due to lack of information. } \\
\text { By gathering and holding discussions between } \\
\text { Junior and Senior staff, a forum for the } \\
\text { management of human resource development } \\
\text { beyond the boundaries of the organization is } \\
\text { provided. }\end{array}$ \\
\hline $\begin{array}{l}\text { 【 Feature (2)】 } \\
\text { Cost estimation staff speaks out and } \\
\text { explains. }\end{array}$ & $\begin{array}{l}\text { Cost estimation staff gives verbal explanations, } \\
\text { which makes it easy to notice incorrect cost } \\
\text { estimations and misunderstandings. } \\
\text { Cost estimation staff explains to other staff and } \\
\text { hence the ability to explain is improved. }\end{array}$ \\
\hline
\end{tabular}

Source: Authors.

\section{Possibility of horizontal deployment of the constructed system}

Regardless of the size of the local government, we believe that adopting this new verification process currently undertaken at the Verification Meeting will lead to improved accuracy of cost estimations. A Verification Meeting requires several staff members from different generations as can be seen from Figure 1 and Tables 2 and 10. When staff levels are low, such as in small local governments, it may not be possible to adopt it. In that case, we suggest using a cost estimation checklist method to prevent missing verification items.

According to Pre-verification staff, it is common practice to perform verification work using only one's eyes to do the task. However, the literature (Gawande, 2011; Staff blog, 2016; Yamaura, 2017; Industrial Innovation Institute Inc., 2017) points out that checklists have become obscure and it is difficult to completely prevent incorrect cost estimation by simply using them. Thus, using a cost 
estimation checklist, we constructed a Simple Verification Meeting as another new cost estimation check system to prevent errors. This enables the horizontal deployment of the check system in smalland medium-sized local governments where it is difficult to allocate a great number of staff members to the task.

In the Simple Verification Meeting, when carrying out verification work using a cost estimation checklist, Cost estimation staff and Pre-verification staff look at each other, the point at items with their fingers, use visual interaction, communicate orally, and listen. The four actions of Pointing and Calling are adopted by a small number of staff, i.e. only two people. By these four actions, the brain is more active, the thinking becomes more positive, and the verification accuracy by using the cost estimation checklist can still be improved. As a result, a Simple Verification Meeting involving two people can be held even by small- and medium-sized local governments that cannot hold a full Verification Meeting with many staff.

\section{Features of the Verification Meeting / Simple Verification Meeting}

The new cost estimation check system is shown in table form so that it can be used immediately. Table 11 shows the names and main roles of each staff member of Verification and Simple Verification Meetings. Table 12 shows the features and the novelty evaluation of the Simple Verification Meeting that partially incorporates the advantages shown in Table 10. Table 13 shows the characteristics and novelty evaluation of the ideal Verification Meeting in which the management of human resources development is also considered in the daily work of participants.

Table 11. Names and main roles of each staff member

\begin{tabular}{|c|l|}
\hline NAME & \multicolumn{1}{|c|}{ MAIN ROLE } \\
\hline Cost estimation staff & Perform cost estimation. \\
\hline Pre-verification staff & $\begin{array}{l}\text { Conduct verification at the preliminary stage of submission to the } \\
\text { Verification Meetings, together with Cost estimation staff. }\end{array}$ \\
\hline Verification staff & $\begin{array}{l}\text { Participate in the Verification Meeting and run individual Verification } \\
\text { Meetings. } \\
\text { Senior staff who plays the role of Verification Leader. }\end{array}$ \\
\hline Secretariat & $\begin{array}{l}\text { Junior staff who participate in the Verification Meeting and assist } \\
\text { Verification staff. }\end{array}$ \\
\hline & $\begin{array}{l}\text { The Deputy Manager who formulates management policies for all } \\
\text { Verification Meetings. }\end{array}$ \\
\hline
\end{tabular}

Source: Authors.

Table 12. Evaluation of features and novelty of the Simple Verification Meeting

\begin{tabular}{|l|c|l|}
\hline \multicolumn{2}{|c|}{ Features } \\
\hline $\begin{array}{l}\text { Constituent } \\
\text { staff }\end{array}$ & \multicolumn{2}{|c|}{$\begin{array}{c}\text { Cost estimation staff 1 person } \\
\text { Pre-verification staff 1 person }\end{array}$} \\
\hline Features (1) & $\begin{array}{c}\text { Novelty } \\
\times\end{array}$ & Use checklist \\
\hline Features (2) & $\begin{array}{c}\text { Novelty } \\
\times\end{array}$ & Cost estimation staff creates explanatory materials \\
\hline Features (3) & $\begin{array}{c}\text { Novelty } \\
0\end{array}$ & $\begin{array}{l}\text { Cost estimation staff uses verbal explanations } \\
\text { (This makes it easier to notice incorrect cost estimations and } \\
\text { misunderstandings) } \\
\text { (The ability to explain improves) }\end{array}$ \\
\hline
\end{tabular}




\begin{tabular}{|c|c|c|}
\hline Features (4) & $\begin{array}{c}\text { Novelty } \\
0\end{array}$ & $\begin{array}{l}\text { Perform a face-to-face check } \\
\text { (Some management of human resources development is possible) }\end{array}$ \\
\hline
\end{tabular}

Table 13. Verification Meeting features and benefits

\begin{tabular}{|c|c|c|}
\hline \multicolumn{3}{|c|}{ Features } \\
\hline $\begin{array}{l}\text { Constituent } \\
\text { staff }\end{array}$ & $\begin{array}{l}\text { Cost estimati } \\
\text { Pre-verificati } \\
\text { Verification s } \\
\text { Verification a } \\
\text { Secretariat }\end{array}$ & $\begin{array}{ll}\text { aff } & 1 \text { person } \\
\text { aff } & 1 \text { person } \\
& 1 \text { person } \\
\text { ant } & 1 \text { person } \\
& 1 \text { person }\end{array}$ \\
\hline Features (1) & $\begin{array}{l}\text { Novelty } \\
\times\end{array}$ & Use checklist \\
\hline Features (2) & $\begin{array}{l}\text { Novelty } \\
\quad \times\end{array}$ & Cost estimation staff creates explanatory materials \\
\hline Features (3) & $\begin{array}{c}\text { Novelty } \\
\quad 0\end{array}$ & $\begin{array}{l}\text { Explanation by word-of-mouth using Cost estimation staff } \\
\text { (This makes it easier to notice incorrect cost estimations and } \\
\text { misunderstandings) (The ability to explain improves) }\end{array}$ \\
\hline Features (4) & $\begin{array}{c}\text { Novelty } \\
\quad\end{array}$ & Conduct a collaborative check by various levels of staff \\
\hline Features (5) & $\begin{array}{c}\text { Novelty } \\
\quad \circ\end{array}$ & $\begin{array}{l}\text { Gather more information from many staff with different years of } \\
\text { experience } \\
\text { (This helps prevent incorrect cost estimations due to lack of } \\
\text { information) }\end{array}$ \\
\hline Features (6) & $\begin{array}{c}\text { Novelty } \\
0\end{array}$ & Have various discussions beyond the boundaries of the organization \\
\hline Features (7) & $\begin{array}{c}\text { Novelty } \\
\quad 0\end{array}$ & $\begin{array}{l}\text { Kind and meticulous management of human resource development } \\
\text { possible in daily work }\end{array}$ \\
\hline
\end{tabular}

Novelty is defined as a new feature compared with the cost estimation check method currently used by many local governments. Based on this, the new check system "Verification Meeting/ Simple Verification Meeting" highlighted five items of novelty, as compared with the conventional verification method of cost estimations.

\section{Conclusions}

The conclusions of this paper are as follows:

1.When the Deputy Manager who received the organization management training was in charge, the tasks were shared equally among the staff. However, in the case of Senior Staff who did not receive the organizational management training, the staff division of labour was not equal. Therefore, the effectiveness of organizational management training was confirmed. 
2. The new check system of cost estimation aimed at preventing errors was constructed and put to actual use for about three years while improvements were made to complete the system.

3. The Verification Meeting involves four actions: everyone pointing with fingers, visual interaction, oral communication and listening. These four actions are the exact basic actions of Pointing and Calling. Therefore, it is not accidental that the Verification Meeting was successful. It was an application of Pointing and Calling and its analysis revealed that it was an effective cost estimation check system.

4. Creating forums for the management of human resources development in daily work is key to the success of professional development for the Junior staff.

5. In the Simple Verification Meeting, when carrying out verification work using a cost estimation checklist, Cost estimation staff and Pre-verification staff look at each other, the point at items with their fingers, use visual interaction, communicate orally and listen to others. The four actions of Pointing and Calling can be adopted by as few as two people. Through these actions, the brain is more active, thinking becomes more positive and the verification accuracy of the cost estimation checklist can be improved. This enables the horizontal deployment of the system to smalland medium-sized local governments where large-scale estimation department staffing is difficult.

We recommend that the "Pointing and Calling" method of safety management, which is the structural theory supporting the Verification Meetings method, be used internationally in many industries. In terms of the value of human resources development, it is considered that there are many similarities between the cost estimation departments of local governments and construction design consultancy companies globally. The structural calculation is not very different throughout the world. Therefore, design consulting companies around the world can avoid structural calculation errors by using the Verification Meeting method as well. In addition, this new method can improve the professional development of young civil engineering staff.

This study is limited in that it is based on the results obtained in one local government in Japan and hence it is necessary to accumulate further experimental results. One drawback of the Verification Meeting is that it requires many people to get together and requires time and effort. The Simple Verification Meeting held by a small number of people has a simpler structure compared to the Verification Meeting. Therefore, it is necessary to carefully consider which method should be used. It is hoped that this new check system of cost estimation will be used in many countries.

Finally, this paper is the result of research based on the ideas of the first author of this study and does not stem from an idea proposed by the local government for which the first author works.

\section{References}

1. Adachi, T. Career Selection of College Students: Its Psychological Background and Support. The Japan Institute for Labor Policy and Training No.533, 2004. https://www.jil.go.jp/institute/zassi/backnumber/2004/12/pdf/027-037.pdf [2019-05-24].

2. Ding, A. Construction Estimating Complete Handbook (2nd ed.). Dewalt, 2016.

3. Gawande, A. Why Don't You Use Checklists? Tokyo: Shinyusha Co., Ltd., 2011.

4. Global Consulting Team. 2018 New Employees Spring Awareness Survey: 80.6\% of firsttime applicants have joined the company. Tokyo: Japan Productivity Center, 2018. https://activity.jpc-net.jp/detail/ird2/activity001536/attached.pdf [2019-05-24].

5. Hashimoto, K. Safety Ergonomics. Tokyo: Japan Industrial Safety and Health Association, 1994.

6. Industrial Innovation Institute Inc. Keyword Explanation: Consideration of Human Error (3) What is Confirmation, 2017. https://www.monodukuri.com/gihou/article/1568 [2019-05-24].

7. Japan International Center for Occupational Safety and Health. Publication of the Main Points to Hazard Prediction Activities (KYT) (multilingual versions), 1999. https://www.jniosh.johas.go.jp/icpro/jicosh-old/english/zero-sai/ [2019-05-24]. 
8. Kasahara, Y., Shimazaki, K., Ishida, T., Hirayama, H., Sakai, M., Kawamura, S. An Experimental Investigation of the Factors on Medication Errors in Nurses' Administering Oral Medications. Japan Human Factors and Ergonomics Society, 2013, Vol. 49, No. 2, p. 62-70. https://www.jstage.jst.go.jp/article/jje/49/2/49_62/_pdf/-char/ja [2019-05-24].

9. Kawada, A., Miyakoshi, Y., Fujii, T., Kobayashi, T., Tamura, S., Teraoka, S. Comparison of Variation in Regional Blood Flow in the Frontal Lobe during Confirmation Tasks Using the "Pointing and Calling" Method. Japanese Journal of Occupational Medicine and Traumatology, 2011, Vol. 59, No. 1, p. 19-26. https://ci.nii.ac.jp/naid/10029838636 [201905-24].

10. Kawasaki City. Port Authority Review Report, 2016a. http://www.city.kawasaki.jp/580/page/0000075462.html [2019-05-24].

11. Kawasaki City. Kawasaki City Human Resources Development Basic Policy, 2016b, p.1 http://www.city.kawasaki.jp/170/cmsfiles/contents/0000076/76432/kihonhousin.pdf [201905-24].

12. Kawasaki City. Kawasaki City Human Resources Development Basic Policy, 2016c, p.19. http://www.city.kawasaki.jp/170/cmsfiles/contents/0000076/76432/kihonhousin.pdf [201905-24].

13. Kawasaki City. Port Authority Review 2018. http://www.city.kawasaki.jp/580/page/0000075462.html [2019-05-24].

14. Kinoshita, S. Public Procurement Dismantling New Book. Economic Research Association, 2017.

15. Kiyomiya, E., Ikeda, T., Tomita, Y. Relationship Between Work Method and Performance in Complex Choice Reaction: Preliminary Study on the Effect of "Pointing and Calling." Bulletin of Railway Labour Science Research Institute, 1965, Vol. 17, p. 289-295.

16. Max Blog. When Does Employee Motivation Go Down? Max Produce Co., Ltd., 2016. https://max-produce.com/blog/motivation [2019-05-24].

17. Japan Ministry of Health, Labour and Welfare. Workplace Safety Site (in Japanese).http://anzeninfo.mhlw.go.jp/yougo/yougo72_1.html [2019-05-24].

18. Mynavi Corporation, Student contact editorial department. Motivation Switch Off! Top 5 Moments When Motivation for Work Falls, 2017. https://gakumado.mynavi.jp/freshers/articles/50090 [2019-05-24].

19. Nagamachi, M. Ergonomics of Safety Management. Kaibundo, 1995.

20. Nambo, M. Business Laver Trend Introductory Column: A Word on the Youth's Occupational Consciousness. The Japan Institute for Labour Policy and Training, 2016. https://www.jil.go.jp/kokunai/blt/backnumber/2016/05/000.pdf [2019-05-24].

21. Netscher, P. Construction Management. Create Space Independent Publishing Platform, 2017.

22. Nikkei Construction. The Actual Situation of the Frequent Occurrence of Incorrect Cost Estimation. Tokyo: Nikkei Business Publications, 2010, Vol. 501, p. 37-40.

23. Nikkei Construction. Incorrect Cost Estimation is Not Disappearing. Tokyo: Nikkei Business Publications, 2013a, Vol. 572, p. 44-47.

24. Nikkei Construction. Pitfalls of Cost Estimation. Tokyo: Nikkei Business Publications, 2013 b.

25. Ohashi, H. Advance Announcement of Ceiling price and Upper Bound. The Nikkan Kensetsu Kogyo Shinbun, 2014.

26. Staff Blog. Check/Confirmation Work Tends to Form. Niigata: WITH UP CO., LTD., 2016. https://www.sksp.co.jp/blog/y-koike/post-38542.php [2019-05-24].

27. Tokyo Future University. Motivation Survey for the Third Year of Working Adults (The First). Tokyo: Tokyo Future University, 2018.

28. Yamaura, K. Incidents in the Operating Room: The Utility of the WHO's Surgical Safety Checklist. Journal of Japan Society for Clinical Anesthesia, 2017, Vol. 37, No. 1, p. 76-80. https://www.jstage.jst.go.jp/article/jjsca/37/1/37_76/_pdf/-char/ja [2019-05-24]. 


\section{Nobuo Nishi, Masaru Minagawa
Nauja tikrinimo sistema, skirta ịvertinti Japonijos vietos valdžios institucijų projekto sąnaudas

Anotacija

Japonijoje „delegavimas ir patikra“ yra žinomas saugos valdymo metodas, siekiant užkirsti kelią klaidoms ir užtikrinti saugumą. Šio tyrimo metu buvo sudaryta ir pasiūlyta nauja tikrinimo sistema „Tikrinimo susitikimas/paprastas patikrinimo susitikimas“, kuri yra pagrịsta delegavimo ir patikros sistema ir kuria siekiama užkirsti kelią neteisingiems viešųjų darbų projektų išlaidų įvertinimams. Naujoji sistema taip pat prisideda prie geresnès darbuotojų moralès ir profesinio tobulejjimo. Šioje sistemoje yra penki nauji elementai, kurie papildo ịprastinę išlaidų vertinimo ir patikros sistemą. Siūloma sistema buvo pritaikyta ir patikrinta Japonijos vietos savivaldoje. Atsižvelgus ị stebėjimų rezultatus sistema dar buvo patobulinta. Todèl maždaug trejus metus kol buvo taikoma ši sistema, nebudo užfiksuota reikšmingų klaidų išlaidų vertinime Uosto ir prieplaukos biure, kuriame dirbo vienas iš straipnio autorių tam tikro. Sistemos priežiūros ir taikymo rezultatai leidžia ją nuolat tobulinti bei adaptuoti pagal skirtingą vietos savivaldos institucijų poreikius ir galimybes, ịskaitant ir tas, kuriose yra nedaug darbuotojų.

Nobuo Nishi works as a civil engineer and assistant manager in a local government in Japan. He also attends graduate school at Tokyo City University. His research interests are construction management and civil engineering.

E-mail: g1891611@tcu.ac.jp

Masaru Minagawa is the vice president and a professor of the Department of Civil and Urban Engineering, Tokyo City University. His research interests are construction management, disaster management, and information technology application in civil engineering.

E-mail: minamasa@tcu.ac.jp

Nobuo Nishi yra as a miestų inžinierius ir projektų koordinatorius vietos savivaldoje Japonijoje. N. Nishi yra Tokijo miesto universiteto doktorantas, tyrinejjantis statybų vadybą bei miestų inžinerijos klausimus.

El. paštas: g1891611@tcu.ac.jp

Masaru Minagawa yra Tokijo miesto universiteto Civilinès ir miestų inžinerijos katedros vadovas ir profesorius. Moksliniai interesai apima statybos valdymas, nelaimių valdymas ir informacinių technologijų taikymas civilinèje inžinerijoje.

El. paštas: minamasa@tcu.ac.jp

This article is an Open Access article distributed under the terms and conditions of the Creative Commons Attribution 4.0 (CC BY 4.0) License (http://creativecommons.org/licenses/by/4.0/ ). 